\title{
Types and Concentrations of Catalysts in Chemical Glycerolysis for the Production of Monoacylglycerols and Diacylglycerols
}

Edy Subroto*, Rossi Indiarto, Aldila Din Pangawikan, Elazmanawati Lembong, Riva Hadiyanti

Department of Food Industrial Technology, Faculty of Agro-Industrial Technology, Universitas Padjadjaran, Jl.Raya BandungSumedang Km. 21, Jatinangor, Sumedang, 40600, Indonesia

\begin{tabular}{l} 
A R T I C L E I N F O \\
\hline Article history: \\
Received: 09 December, 2020 \\
Accepted: 23 January, 2021 \\
Online: 30 January, 2021 \\
\hline Keywords: \\
Glycerolysis \\
Catalyst \\
Monoacylglycerol \\
Diacylglycerol \\
Structured lipid \\
\hline
\end{tabular}

A B S T R A C T
Monoacylglycerol (MAG) and diacylglycerol (DAG) are structured lipids that have been
widely used in various pharmaceutical, cosmetic, and food industries. MAG and DAG are
generally produced by chemical glycerolysis. Chemical catalysts have been shown to be
more efficient, economical, and effective. This study summarizes and discusses the factors
that affect the synthesis of MAG and DAG by chemical glycerolysis, such as temperature,
reaction time, and type and concentration of catalysts that affect the resulting MAG and
DAG concentrations. Homogeneous catalysts such as KOH and NaOH are very effective for
generating MAG and DAG conversions up to $91 \%$, but they have a disadvantage, mainly
because they cannot be used repeatedly. However, heterogeneous catalysts have great
potential to be developed into catalysts with high activity, environmentally friendly, and can
be used repeatedly.

\section{Introduction}

The need for emulsifiers is increasing along with the development of emulsion-based food products, especially emulsifiers from the mixture of monoacylglycerols and diacylglycerols, which are the most considerably used in the food industry, which is about 75\% [1]. Commercially, MAG and DAG are used in food products such as cake products, butter, margarine, and confectionaries because they have good emulsification, stabilization, and conditioning properties [2,3]. Mono and diacylglycerols are also used in the pharmaceutical, cosmetic, textile, and plastic industries in consequence of their plasticizing and lubricating properties [4,5]. Applications of MAG and DAG in various products can be seen in Table 1.

Naturally, MAG and DAG are minor components in various vegetable oils with a maximum content of $10 \%$ [6]. MAG consists of three isomers, namely enantiomers (sn-1 and sn-3) and regioisomers (sn-2) [7]. DAG be composed of 2 fatty acyl chains, which are esterified into glycerol backbone and can have the shape of 1,3-DAG and 1,2 (or 2,3)-DAG [8]. MAG and DAG are non-ionic molecules that have a free hydroxyl group, which is a hydrophilic group, and a fatty acid ester group, which is a lipophilic group [9]. The double affinity of MAG and DAG or often called amphiphilic, means that they can be used as emulsifiers. MAG with one fatty acid group and two free hydroxyl

*Corresponding Author: Edy Subroto, Email: edy.subroto@unpad.ac.id www.astesj.com

https://dx.doi.org/10.25046/aj060166 groups on glycerol makes it behave like fat and water. MAG is an emulsifier that is not very sensitive to acidic conditions. The way the emulsifier works is by lowering the surface tension between the two phases and then stabilizing the products [10].

Commercially, the synthesis of MAG and DAG can be conducted by various methods, namely glycerolysis, direct esterification, and partial or alcoholic hydrolysis [5]. Various types of catalysts are also used, such as homogeneous base catalysts, heterogeneous bases, homogeneous acids, and heterogeneous acids. Several studies have shown a relatively high yield when using a homogeneous base catalyst and a heterogeneous base catalyst, while acid catalysts produce a relatively lower yield. In general, the synthesis of MAG and DAG on a large scale is carried out using the chemical glycerolysis method of oil, which is reacted with glycerol using an alkaline catalyst (such as $\mathrm{NaOH}$ and $\mathrm{KOH}$ ) at high temperatures [2,11].

Table 1: Applications of MAG and DAG in Various Products.

\begin{tabular}{|l|l|c|}
\hline Source of MAG/DAG & \multicolumn{1}{|c|}{ Products } & References \\
\hline Palm-based oils/fats & Emulsifier & {$[12]$} \\
\hline Palm oils & Emulsifier & {$[13]$} \\
\hline Vegetable oil & Emulsifier & {$[14]$} \\
\hline Palm mild fraction & Shortening & {$[15]$} \\
\hline $\begin{array}{l}\text { Sunflower oil, palm } \\
\text { kernel olein }\end{array}$ & Margarine & {$[16]$} \\
\hline
\end{tabular}




\begin{tabular}{|l|l|r|}
\hline Chicken fat & Structured fat & {$[17]$} \\
\hline Corn oil & MAG-DAG Oils & {$[18]$} \\
\hline Vegetable oils & MAG-DAG Oils & {$[19]$} \\
\hline Palm olein & MAG-DAG Oils & {$[20]$} \\
\hline Monostearate & Oleogels & {$[21]$} \\
\hline $\begin{array}{l}\text { Monostearate, } \\
\text { monopalmitate }\end{array}$ & Organogels & {$[22]$} \\
\hline Saturated fat & Organogels & {$[23]$} \\
\hline Saturated fat & Oleogels & {$[24]$} \\
\hline
\end{tabular}

Chemical glycerolysis at high temperature has several disadvantages, such as dark-colored products and high energy consumption. Several studies have reported that chemical glycerolysis of oils and fats can produce MAG and DAG of about $45-55 \%$ and $38-45 \%$, respectively [3]. Subsequent molecular distillation is required to acquire monoacylglycerols with a purity of $90 \%$ [25], needed for the pharmaceutical, cosmetic, and food industries. Recent research studies about the glycerolysis reaction at low temperatures using a solvent or without a solvent; the concentration of MAG and DAG generated by this reaction ranges from $40-80 \%$ [26].

Another alternative used to substitute chemical catalysts is to use enzyme catalysts [27]. However, the use of enzymes has several drawbacks, such as the glycerolysis reaction requires special conditions and slow reaction kinetics. Besides, the high price of enzymes is a consideration for industrial applications [4]. The use of cheap and easy to obtain raw materials is an important factor in the manufacture of MAG and DAG on an industrial scale. Over the past few years, means have been made to produce high MAG using chemicals and enzymes as catalysts, and methods have been promoted with the aim of increasing the yield of MAG and DAG [28].

Various methods and various types of catalysts can be used to produce MAG and DAG, which can be applied to various food industries. This study discusses the effect of various types of chemical catalysts and their concentrations on the production of MAG and DAG using the glycerolysis method by considering other factors such as the molar ratios of oil to glycerol, temperature, and reaction time. In addition, the $\mathrm{NaOH}$ catalyst, which is a homogeneous catalyst, has not been widely discussed, so it is interesting to study in-depth because it has high catalytic activity and is efficient.

\section{Characteristics of Mono- and Diacylglycerols}

MAG and DAG are non-ionic molecules that have hydrophilic and hydrophobic groups [9]. MAG is an anionic emulsifier with excellent emulsifying properties because it has two hydrophilic groups (hydroxyl) and one hydrophobic group on the fatty acid chain. These emulsifying characteristics are used in food products, cosmetics, plasticizers, detergents, and pharmaceutical formulations [29]. On the other hand, DAG can be used as an emulsifier, especially in emulsion systems of water in oil $(\mathrm{o} / \mathrm{w})$. DAG can also effectively prevent the accumulation of fat and diseases related to obesity, so it is often used as a functional ingredient and including lipids that are good for health [30].

MAG and DAG are needed in almost all types of food products. Its main use includes bakery products, margarine,

convenience foods, and frozen desserts. MAG and DAG are used as part of fat products and are often associated with other emulsifiers. Lipophilic characteristics cause MAG and DAG to have excellent properties as emulsifiers in water in oil (w/o) system, as required in the manufacture of margarine and shortening [15,16,31].

One of the uses of MAG and DAG is as an emulsifier. The use of emulsifiers is to maintain moisture and softness of bakery products, improve the stability of crystal emulsions in ice cream products, reduce stickiness in candy products, and so on [32]. In addition, other uses of emulsifiers are maintaining emulsion stability in margarine, preventing fat bloom in chocolate products, and improving palatability in cake products [33].

Based on research in [34], the emulsification ability produced from an emulsifier containing a mixture of $91 \%$ MAG and $9 \%$ DAG was stable when compared to commercial emulsifiers because the emulsion capacity was $95.55 \%$ after heating, the percent stability of the emulsion only decreased a little, namely to be $90.44 \%$. Based on research in [35], the emulsification ability produced from a mixture of $50.89 \%$ DAG and $11.68 \%$ MAG had emulsion stability of about $95.44 \%$ and an emulsion capacity of $93.63 \%$.

The melting point of MAG and DAG is higher than their triacylglycerol forms. The difference in melting points is caused by the difference in the number of hydrogen bonds in the carboxyl bonds and the hydrophobic interactions along the hydrocarbon chains. The melting point increases as the MAG and DAG content in the fat/oil increases [36]. MAG has a faster crystal conformation compared to TAG [37]. MAG and DAG can be utilized separately (pure of MAG and pure of DAG) or simultaneously. The application of MAG as an emulsifier requires high purity because MAG has better emulsification characteristics than different acylglycerol mixtures [38].

Food emulsifiers are generally in the form of semisolids containing fatty acids such as stearic, lauric, palmitic, and oleic acids. In general, the commercially saturated MAG is MAG containing stearic acid. Saturated MAG has a high melting point but has restricted emulsifying characteristics. Nevertheless, unsaturated MAG has a modest structure but is restricted in application due to its low oxidation stability [39].

A decrease in oxidation stability can be caused by changes in the position of fatty acids in the acylglycerol structure, include MAG and DAG [40]. Partial hydrogenation can be an effective way to rectify the oxidative stability of fats/oils [41]. Zhang et al. [39] conducted a study that rivets on partial hydrogenation of corn oil to increase the MAG oxidation stability of corn oil. The oxidation stability measured based on the induction period (IP) value of the MAG from the hydrogenation of corn oil was 13.68 hours, while the IP value of the MAG of corn oil was 0.51 hours. Thus, hydrogenation increases oxidation stability. However, partial hydrogenation can lead to the formation of trans-fats, which can be harmful to health.

\section{Synthesis Methods of Mono- and Diacylglycerols}

\subsection{Enzymatic Methods}

The enzymatic synthesis method can be carried out through esterification, alcoholysis or hydrolysis, and glycerolysis. Highly 
stable lipases in solvents offer the potentiality of using a variety of approaches for catalyzed enzyme synthesis, such as selective alcoholysis or hydrolysis by specific lipases, glycerolysis of oils/fats, and esterification of free fatty acids with glycerol [42]. The reaction of glycerolysis by enzymatic catalysts has been extensively investigated using low temperatures $\left(<80{ }^{\circ} \mathrm{C}\right)$ to generate MAG and DAG. MAG and DAG resulting from the enzymatic glycerolysis have good quality, but enzymatic glycerolysis has several shortfalls, including limited availability of enzymes, low reactant conversion factors, long reaction times, and high cost [43]. In addition, enzymatic glycerolysis has low efficiency, which is largely due to the inhomogeneous nature of oil or fat with lipophilic properties and lipase enzymes with hydrophilic characteristics when the reaction is carried out at low temperatures. It is notable for maintaining homogeneity between oil or fat and enzymes using the suitable solvent [44].

Based on research in [45], the glycerolysis between several samples of oil and fat with glycerol using lipase as a catalyst without using solvents and emulsifiers in a batch system produced $90 \%$ MAG resulting from the glycerolysis of olive oil, while the lowest yield was $30 \%$ that results from hydrogenated fat. Based on research in [3], the glycerolysis reaction of sunflower oil samples using Novozyme 435 with tert-pentanol and tert-butanol as the single solvent produced MAG in the range of $68-82 \%$.

Based on research in [46], the enzymatic glycerolysis reaction of Lipozyme TL IM 15\% using tert-butanol and isopropanol $(80 / 20 \mathrm{w} / \mathrm{w})$, glycerol to oil molar ratio 3.5: 1 , and solvent to oil ratio $4: 1$, at a temperature of $45^{\circ} \mathrm{C}$ for 4 hours produced MAG about $72 \%$. In [4], the author compared the glycerolysis between the enzyme-catalyzed reaction and the $\mathrm{NaOH}$-catalyzed reaction. The reaction rate of the $\mathrm{NaOH}$ catalyzed was faster than the Novozym 435. Although the enzymatic approach has yielded good results; nevertheless, the high cost, reaction rate, and stability of the catalyst remain major barriers to the wide-spread use of enzymes for the commercial production of MAG and DAG.

\subsection{Chemical Methods}

Commercially MAG and DAG can be produced through several methods, namely: (i) direct esterification with fatty acids catalyzed by strong acids such as $\mathrm{H}_{3} \mathrm{PO}_{4}$ or $\mathrm{H}_{2} \mathrm{SO}_{4}$ at a high temperature of $90-120^{\circ} \mathrm{C}$ or alkaline catalysts, (ii) glycerolysis of oil or fat which is catalyzed by homogeneous bases such as $\mathrm{KOH}$ or $\mathrm{NaOH}$ at a high temperature of $120-260{ }^{\circ} \mathrm{C}$ under an inert atmosphere, (iii) transesterification of fatty acid esters and (iv) partial or alcoholic hydrolysis $[2,47]$.

In [48], the direct esterification using the ratio between lauric acid and glycerol of $1: 1$ at $112{ }^{\circ} \mathrm{C}$ using a mesoporous sulfonate catalyst $0.5 \%(\mathrm{w} / \mathrm{w})$ produced MAG with a concentration of $53 \%$. Meanwhile, under the same reaction conditions, but using Amberlyst- 15 as a catalyst, it produced MAG with a concentration of $44 \%$. The MAG produced using a mesoporous sulfonate catalyst was higher because it contains alkyl, and sulfonic acid can act as a catalyst [49]. In [50], the heterogeneous catalyst Amberlyst- 15 was affected by several factors, namely the pore diameter and catalyst surface area. The use of $\mathrm{H}_{2} \mathrm{SO}_{4}$ as a homogeneous acid catalyst at a lauric acid and glycerol ratio of $1: 1$, a temperature of $130{ }^{\circ} \mathrm{C}$ for 6 hours, and a $5 \%(w / w) \mathrm{H}_{2} \mathrm{SO}_{4}$ catalyst produced $31.05 \%$ monolaurin after going through a purification using column chromatography techniques [51].

Most of the MAG and DAG is generated by glycerolysis of TAG with excess glycerol at high temperatures in the presence of a catalyst. The addition of a catalyst to the glycerolysis reaction aims to acquire a high conversion in a relatively short time. This reaction can be performed in the existence of a base catalyst or an acid catalyst. The reaction with an alkaline catalyst is usually faster than an acid catalyst [52].

The glycerolysis reaction occurs randomly following the equilibrium to produce a certain composition of MAG, DAG, and TAG. Theoretically, the glycerolysis reaction involves 2 moles of glycerol, which will react with 1 mole of TAG and generate 3 moles of MAG. The glycerolysis reaction is used in producing MAG and DAG because it is more economical in terms of raw material prices and requires less glycerol [53]. According to [4], $\mathrm{KOH}$ and $\mathrm{NaOH}$ are catalysts that are more effective in their use in the glycerolysis process at low temperatures compared to $\mathrm{SiO}_{2}$ and $\mathrm{Al}_{2} \mathrm{O}_{3}$.

\section{Types and Concentrations of Catalysts for Chemical Glycerolysis}

Chemically synthesizing MAG and DAG by glycerolysis requires a catalyst. Catalysts are substances that speed up reactions but do not react with them. The catalyst speeds up the reaction by decreasing the activation energy. The greater the concentration of catalyst and reaction temperature, the greater the reaction rate so that the product produced is also more significant [54]. Catalysts can be classified into two types, namely homogeneous catalysts and heterogeneous catalysts. The catalyst selectivity has several differences. Homogeneous catalysts are generally used for universal substrate types but are only suitable for batch reactors and cannot be used in continuous systems. In comparison, heterogeneous catalysts are more suitable for substrates or reactants that are less viscous and suitable for reactions in continuous systems [55].

In the use of a homogeneous catalyst, the catalyst is in the same phase as the reactants. The reactants and catalyst are in a single phase of liquid or gas. There are two types of homogeneous catalysts, namely homogeneous acid catalysts and homogeneous base catalysts. Homogeneous base catalysts for glycerolysis include $\mathrm{KOH}$ and $\mathrm{NaOH}$ [56]. These catalysts have advantages related to their characteristics, including high catalytic activity that only requires a short reaction time, low cost, high stability, and easy use [57]. There are also homogeneous catalysts in the form of homogeneous acid catalysts, include $\mathrm{H}_{2} \mathrm{SO}_{4}, \mathrm{HCl}$, and $\mathrm{H}_{3} \mathrm{PO}_{4}$. However, the utilize of a homogeneous acid catalyst requires a long reaction time, causes corrosion in the reactor, and requires high temperatures [58].

In the use of heterogeneous catalysts, the catalyst and reactants are in different phases. Heterogeneous catalysts tend to be easier to separate and reuse from the reaction mixture because the phase used is different from the reaction product. The heterogeneous catalyst used is in the form of a solid phase while the reactants are liquid [59]. The most commonly used heterogeneous base catalysts are alkaline earth metal oxides compounds, such as $\mathrm{MgO}, \mathrm{CaO}, \mathrm{SrO}$, and $\mathrm{BaO}[60]$. 
Apart from metal oxide catalysts, there are several non-oxide catalysts that can be used, including 1-Butyl-3Methylimidazolium Imidazolide [61]. The catalyst is also effectively used in chemical glycerolysis to produce DAG reaching about $60 \%$ at a concentration of $15 \%$, a temperature of $80{ }^{\circ} \mathrm{C}$ for 4 hours.
Chemical catalysts are more widely used because they are easier to handle, cost less, easy to separate, and can be used in relatively low concentrations. Several types of chemical catalysts used in the glycerolysis reaction for the production of MAG and DAG are presented in Table 2.

Table 2: Several Types of Chemical Catalysts Used in the Glycerolysis Reaction for the Production of MAG and DAG.

\begin{tabular}{|c|c|c|c|c|c|}
\hline No & Catalysts & Source of fat/oil & Reaction condition & $\begin{array}{c}\text { Yield of } \\
\text { MAG \& DAG }\end{array}$ & References \\
\hline 1 & $\mathrm{NaOH} 0.18 \%$ & Soybean oil & $\begin{array}{l}\text { The molar ratio of oil:glycerol (1:2.5), } \\
\qquad 230^{\circ} \mathrm{C}, 25 \mathrm{~min}\end{array}$ & $58 \% \& 33 \%$ & [27] \\
\hline 2 & $\mathrm{NaOH} 3 \%$ & $\begin{array}{l}\text { Palm olein and } \\
\text { palm stearin }\end{array}$ & $\begin{array}{l}\text { The molar ratio of oil: glycerol }(1: 1.5) \text {, } \\
\text { in tert-butanol, molecular sieve } 12 \% \text {, at } \\
\qquad 80^{\circ} \mathrm{C} \text { for } 3 \mathrm{~h}\end{array}$ & $58.64 \%$ & {$[35]$} \\
\hline 3 & $\mathrm{NaOH} 0.3 \%$ & Palm oil & $\begin{array}{l}\text { The molar ratio of oil:glycerol (1:2), } \\
\qquad 240^{\circ} \mathrm{C}, 60 \mathrm{~min}\end{array}$ & $58 \%$ & [62] \\
\hline 4 & $\mathrm{NaOH} 0.45 \%$ & Soybean oil & $\begin{array}{c}\text { Glycerol 4,6 g; Oil } 8.8 \mathrm{~g} \text {; in t-butanol; } \\
50^{\circ} \mathrm{C}, 1 \mathrm{~h}\end{array}$ & $81.76 \%$ & [4] \\
\hline 5 & $\mathrm{NaOH} 2 \%$ & Palm stearin & $\begin{array}{l}\text { The molar ratio of oil:glycerol (1:2.5), } \\
\qquad 200^{\circ} \mathrm{C} ; 20 \mathrm{~min}\end{array}$ & $65.4 \%$ & [1] \\
\hline 6 & $\mathrm{NaOH} 3 \%$ & $\begin{array}{l}\text { RBD Palm } \\
\text { stearin }\end{array}$ & $\begin{array}{l}\text { The molar ratio of oil: glycerol (1:5), in } \\
\text { tert-butanol, molecular sieve } 13 \% \text {, at } \\
\qquad 90^{\circ} \mathrm{C} \text { for } 6 \mathrm{~h}\end{array}$ & $\begin{array}{l}91.00 \% \\
\& \\
9.00 \%\end{array}$ & [34] \\
\hline 7 & $\mathrm{KOH} 0.45 \%$ & Soybean oil & $\begin{array}{l}\text { Glycerol 4,6 g; Oil } 8.8 \mathrm{~g} ; \text { in t-butanol; } \\
\text { catalyst } 0.04 \mathrm{~g} ; 50^{\circ} \mathrm{C}, 1 \mathrm{~h}\end{array}$ & $68 \%$ & [4] \\
\hline 8 & Amberlyst-15 & $\begin{array}{l}\text { RBD Palm } \\
\text { stearin }\end{array}$ & $\begin{array}{l}\text { The molar ratio of oil: glycerol (1:5), in } \\
\text { tert-butanol, } 90^{\circ} \mathrm{C}, 9 \mathrm{~h}\end{array}$ & $\begin{array}{c}16.44 \% \\
\& \\
14.49 \%\end{array}$ & [34] \\
\hline 9 & $\mathrm{MgO}$ & Rapeseed oil & $\begin{array}{l}\text { The molar ratio of oil:glycerol (1:4), } \\
\qquad 249.85^{\circ} \mathrm{C}, 2 \mathrm{~h}\end{array}$ & $66 \%$ & [29] \\
\hline 10 & $\mathrm{Ca}(\mathrm{OH})_{2} 1 \%$ & Sunflower oil & $\begin{array}{l}\text { The molar ratio of oil:glycerol (1:4), } \\
\qquad 200^{\circ} \mathrm{C}, 1 \mathrm{~h}\end{array}$ & $48.3 \% \& 42.3 \%$ & [63] \\
\hline 11 & $\begin{array}{l}\mathrm{CuO}-\text { nano }^{+} \\
\mathrm{NaOH} 0.3 \%\end{array}$ & Palm oil & $\begin{array}{l}\text { The molar ratio of oil:glycerol (1:2), } \\
\qquad 240^{\circ} \mathrm{C}, 40 \mathrm{~min}\end{array}$ & $71 \%$ & {$[62]$} \\
\hline 12 & $\mathrm{ZnO}-\mathrm{CaO} / \mathrm{AlO}_{3}$ & Rapeseed oil & $\begin{array}{l}\text { The molar ratio of oil:glycerol (1:4), } \\
\qquad 249.85^{\circ} \mathrm{C}, 2 \mathrm{~h}\end{array}$ & $57 \%$ & [29] \\
\hline 13 & $\begin{array}{l}\text { 1-butyl-3- } \\
\text { methylimidazoliu } \\
\text { m imidazolide }\end{array}$ & Soybean oil & $\begin{array}{c}\text { Catalyst concentration if } 15 \%, \\
\text { glycerol/TAG mole ratio was } 5: 1,80^{\circ} \mathrm{C} \text {, } \\
4 \mathrm{~h}\end{array}$ & $17.4 \% \& 61.7 \%$ & [61] \\
\hline
\end{tabular}

The reaction mechanism of the glycerolysis catalyzed by homogeneous and heterogeneous chemical catalysts is almost the same but has some differences, especially in the active groups of cations or anions that are owned by heterogeneous catalysts. The chemical glycerolysis mechanism is described as follows. In glycerolysis using a homogeneous catalyst such as $\mathrm{NaOH}$, in the early stages, the hydrogen in the glycerol molecule is abstracted by $\mathrm{NaOH}$, which is a strong base to form sodium glyceroxides, which then easily form glyceroxides at high temperatures (90$240{ }^{\circ} \mathrm{C}$ ). Meanwhile, the $\mathrm{OH}$ - anion produced from $\mathrm{NaOH}$ can act as a proton abstraction agent that can attract protons from the $\mathrm{OH}$ group on glycerol by forming surface glyceroxides. $\mathrm{Na}^{+}$cations also take part in the stabilization of negatively charged intermediates. In this condition, the $\mathrm{Na}^{+}$cation also plays a role in activating the triacylglycerol molecule (polarization of the $\mathrm{C}=\mathrm{O}$ bond). The $\mathrm{Na}^{+}$cation further assists or facilitates the overrun of the glyceroxide anion on the positively charged carbonyl carbon present in the TAG. In a later stage, there is a nucleophilic attack on the carbonyl group of the TAG by the glyceroxides to produce MAG and the appropriate anion of 1,3 or 1,2-DAG known as diglyceroxide. The next stage is the conformation of the suitable alkyl ester (DAG) and glycerol anions (glyceroxides) by the second molecule of glycerol reacting with the adsorbed diglyceroxide. In the last stage, the alteration of TAG or DAG to MAG is carried out following the same mechanism. In contrast to homogeneous catalysts, heterogeneous catalysts that act to abstract hydrogen on the glycerol molecule are not $\mathrm{Na}^{+}$cations, but depending on the active groups that heterogeneous catalysts have, for example, are sulfonic or $\mathrm{CuO}$ groups. In addition to acting in hydrogen abstraction, this group also plays a role in 
polarizing the ester group $(\mathrm{C}=\mathrm{O})$ on TAG. Meanwhile, the other mechanism stages are almost the same, namely through nucleophilic attacks and ending with the conversion of TAG and DAG to MAG $[64,65]$.

Table 2 shows that the type and concentration of the catalyst affect the results of the MAG and DAG concentrations. However, glycerolysis is also influenced by reaction conditions (temperature, the molar ratio of oil to glycerol, and reaction time). Homogeneous catalysts and heterogeneous catalysts have advantages and disadvantages. Homogeneous catalysts such as $\mathrm{NaOH}$ or $\mathrm{KOH}$ are preferred because they can readily dissolve and react with glycerol in the reactant system. Based on research in [34], the MAG produced followed by fractionation was $91.00 \%$. The increase in MAG levels is due to differences in the melting point and the thermomechanical separation process through crystallization, namely MAG, which has a higher melting point, will be separated from DAG and TAG with lower melting points. At a fractionation temperature of $30{ }^{\circ} \mathrm{C}$, MAG will crystallize while DAG and TAG remain dissolved in hexane and then filtered. In addition to fractionation, molecular distillation can increase monoacylglycerols with a purity of $90 \%$ [25].

Based on research in [62], using the homo-hetero system in the glycerolysis reaction resulted in almost the same triacylglycerol conversion using either $\mathrm{NaOH}$ or $\mathrm{CuO}$-nano + $\mathrm{NaOH}$ catalysts. However, the product distribution was different where the MAG concentration in the use of a CuO-nano $+\mathrm{NaOH}$ catalyst is higher than the reaction using a $\mathrm{NaOH}$ catalyst. The adjunct of a small amount of $\mathrm{NaOH}(0.01 \% \mathrm{w} / \mathrm{w})$ could increase the TAG conversion. In addition, the catalyst systems of $\mathrm{CuO}-$ nano $+\mathrm{NaOH}$ showed an increase in the yield of TAG to MAG conversion, reaching $90 \%$. The use of $\mathrm{CuOnano}+\mathrm{NaOH}$ catalyst resulted in a higher yield MAG than for the $\mathrm{NaOH}$ system; this shows that in the reaction system, $\mathrm{CuO}$ also acts as a catalyst.

Based on the results of the research that has been conducted, it is possible to consider three main factors that affect the glycerolysis process. These three factors are the strength of the base catalyst, the radius of the catalyst pore, and the solubility of the catalyst in the glycerol and oil system [29]. In the research of [29], using a $\mathrm{ZnO}-\mathrm{CaO} / \mathrm{AlO}_{3}$ catalyst, the results of the MAG concentration were lower than using the $\mathrm{MgO}$ catalyst. Based on research in [4], by comparing eight commonly used basic catalysts, namely $\mathrm{Al}_{2} \mathrm{O}_{3}, \mathrm{SiO}_{2}, \mathrm{MgO}, \mathrm{Na}_{2} \mathrm{CO}_{3}, \mathrm{~K}_{2} \mathrm{CO}_{3}, \mathrm{CaO}, \mathrm{KOH}$, and $\mathrm{NaOH}$. Only $\mathrm{NaOH}$ and $\mathrm{KOH}$ are effective in catalyzing chemical glycerolysis at low temperature $\left(50^{\circ} \mathrm{C}\right)$.

The homogeneous catalysts $(\mathrm{KOH}$ and $\mathrm{NaOH})$ have high catalytic activity and result in high product yields [66]. The reason for this case remains to be investigated. This is also thought to be caused by differences in the capability to extract hydrogen from glycerol. Both $\mathrm{KOH}$ and $\mathrm{NaOH}$ have the same solubility in the tert-butanol. However, at temperatures higher than $240{ }^{\circ} \mathrm{C}$, the $\mathrm{Ca}(\mathrm{OH})_{2}, \mathrm{MgO}$, and $\mathrm{CaO}$ catalysts are all functioning even in solvent-free systems, which exhibit easier alkoxide formation [67]. This is also supported by several studies presented in Table 1 , that a high temperature of $200-250{ }^{\circ} \mathrm{C}$ produces a high MAG concentration of $77 \%$ (solvent-free system). Therefore, high temperature not only increases the solubility of oil/fat and glycerol but also helps the catalyst to extract hydrogen from glycerol to create alkoxides.

According to [5], the surface polarity of the catalyst has a key role in increasing the concentration of MAG and DAG. The glycerol concentration on the catalyst surface will be greater than the fatty acid ester for MAG formation because the high glycerol concentration will limit the forming of DAG and TAG. However, hydrophobic oils also have difficulty accessing the surface of the catalyst, thus reducing the reaction kinetics. Therefore, the catalyst must be very active, the reaction temperature used is higher, and also use a solvent to accelerate the reaction [68].

As previously explained, the glycerolysis reaction is a slowrunning reaction without the addition of a catalyst. The use of various concentrations of $\mathrm{NaOH}$ is also expected to produce high mono- and diacylglycerols. According to [4], the catalyst concentration influences the reaction rate over a particular range, an increase in the $\mathrm{NaOH}$ concentration causes an increase in the reaction rate. The concentration of catalyst affects the yield of the resulting product; the higher the concentration of the catalyst in the solution, the smaller the activation energy of a reaction, so that more products will be formed [69]. However, the addition of excessive catalyst concentration can also encourage the reaction to form soap [70].

Various researches to get the type of catalyst in the glycerolysis reaction continue to develop. Recommendations that can be taken from this review are that $\mathrm{NaOH}$ catalysts are very effective catalysts for chemical glycerolysis reactions, but have the disadvantage of not being used repeatedly, are not environmentally friendly, and cannot be used for continuous reaction systems. Therefore, a more in-depth research is needed, especially on heterogeneous catalysts, in order to obtain a catalyst that is inexpensive, high activity, stable, able to be used repeatedly, can be used for continuous reaction systems, and environmentally friendly.

\section{Conclusion}

Research on the synthesis of MAG and DAG has been carried out using various enzymatic and chemical methods. Chemical catalysts have been shown to be efficient and effective catalysts, so that the chemical glycerolysis is an effective and efficient method for MAG and DAG production. However, the type and concentration of catalysts are very influential in chemical glycerolysis. Catalyst activity is affected by three main factors, namely the strength of the base catalyst, the radius of the catalyst pore, and the solubility of the catalyst in the glycerol and oil system. Homogeneous catalyst $(\mathrm{NaOH})$ concentrations of $0.2-0.5 \%$ produce high yields of MAG and DAG (in the solvent systems). In the solvent-free systems, $\mathrm{NaOH}$ at concentrations of $3 \%$ produces high yields of MAG and DAG. Homogeneous catalysts such as $\mathrm{NaOH}$ and $\mathrm{KOH}$ are very effective for generating MAG and DAG conversions up to $91 \%$, but they have a disadvantage, especially in that they cannot be used repeatedly. However, heterogeneous catalysts have great potential to be developed into catalysts with high activity, environmentally friendly, and can be used repeatedly.

\section{Conflict of Interest}


The authors declare no conflict of interest.

\section{Acknowledgment}

The authors would like to thank you to the Rector of Universitas Padjadjaran and The Ministry of Education and Culture of the Republic of Indonesia. This research is part of an internal research grant "Riset Percepatan Lektor Kepala (RPLK) from Universitas Padjadjaran with contract number 1427/UN6.3.1/LT/2020.

\section{References}

[1] P. Chetpattananondh, C. Tongurai, "Synthesis of High Purity Monoglycerides from Crude Glycerol and Palm Stearin," Songklanakarin Journal of Science and Technology, 30(4), 515-521, 2008.

[2] E. Subroto, "Monoacylglycerols and diacylglycerols for fat-based food products: a review," Food Research, 4(4), 932-943, 2020, doi:10.26656/fr.2017.4(4).398.

[3] M.L. Damstrup, T. Jensen, F. V. Sparsø, S.Z. Kiil, A.D. Jensen, X. Xu, "Solvent optimization for efficient enzymatic monoacylglycerol production based on a glycerolysis reaction," Journal of the American Oil Chemists' Society, 82(8), 559-564, 2005, doi:10.1007/s11746-005-1109-y.

[4] N. Zhong, L. Li, X. Xu, L.Z. Cheong, Z. Xu, B. Li, "High Yield of Monoacylglycerols Production Through Low-temperature Chemical and Enzymatic Glycerolysis," European Journal of Lipid Science and Technology, 115(6), 684-690, 2013, doi:10.1002/ejlt.201200377.

[5] N. Zhong, L.Z. Cheong, X. Xu, "Review Article : Strategies to Obtain High Content of Monoacylglycerols," European Journal of Lipid Science and Technology, 116(Scheme 1), 97-107, 2014, doi:10.1002/ejlt.201300336.

[6] B.D. Flickinger, N. Matsuo, "Nutritional Characteristics of DAG Oil," Lipids, 38(2), 129-132, 2003, doi:10.1007/s11745-003-1042-8.

[7] L. Deng, H. Nakano, Y. Iwasaki, "Direct Separation of Regioisomers and Enantiomers of Monoacylglycerols by Tandem Column High-performance Liquid Chromatography," Journal of Chromatography A, 1165(1-2), 93-99, 2007, doi:10.1016/j.chroma.2007.07.073.

[8] E.T. Phuah, T.K. Tang, Y.Y. Lee, T.S.Y. Choong, C.P. Tan, O.M. Lai, "Review on the Current State of Diacylglycerol Production Using Enzymatic Approach," Food and Bioprocess Technology, 8(6), 1169-1186, 2015, doi:10.1007/s11947-015-1505-0.

[9] B.L.A.P. Devi, H. Zhang, M.L. Damstrup, Z. Guo, L. Zhang, B.M. Lue, X. $\mathrm{Xu}$, "Enzymatic synthesis of designer lipids," OCL - Oleagineux Corps Gras Lipides, 15(3), 189-195, 2008, doi:10.1684/ocl.2008.0194.

[10] A. Zaelani, "Sintesis Mono dan Diasilgliserol Dari Refined Bleached Deodorized Palm Oil (RBDPO) dengan Cara Gliserolisis Kimia," in Fakultas Teknologi Pertanian IPB, Bogor, 2007.

[11] F.O. Nitbani, P.J.P. Tjitda, B.A. Nurohmah, H.E. Wogo, "Preparation of fatty acid and monoglyceride from vegetable oil," Journal of Oleo Science, 69(4), 277-295, 2020, doi:10.5650/jos.ess19168.

[12] Y. Fu, R. Zhao, L. Zhang, Y. Bi, H. Zhang, C. Chen, "Influence of acylglycerol emulsifier structure and composition on the function of shortening in layer cake," Food Chemistry, 249(September 2017), 213-221, 2018, doi:10.1016/j.foodchem.2017.12.051.

[13] K. Hattori, B. Dupuis, B.X. Fu, N.M. Edwards, "Effects of monoglycerides of varying fatty acid chain length and mixtures there of on sponge-and-dough breadmaking quality," Cereal Chemistry, 92(5), 481-486, 2015, doi:10.1094/CCHEM-12-14-0267-R.

[14] J.M. Maruyama, F.A.S.D.M. Soares, N.R. D’Agostinho, M.I.A. Goncalves, L.A. Gioielli, R.C. da Silva, "Effects of Emulsifier Addition on the Crystallization and Melting Behavior of Palm Olein and Coconut Oil," Journal of Agricultural and Food Chemistry, 62, 2253-2263, 2014, doi:10.1021/jf405221n.

[15] R.A. Latip, Y.Y. Lee, T.K. Tang, E.T. Phuah, C.P. Tan, O.M. Lai, "Physicochemical properties and crystallisation behaviour of bakery shortening produced from stearin fraction of palm-based diacyglycerol blended with various vegetable oils," Food Chemistry, 141(4), 3938-3946, 2013, doi:10.1016/j.foodchem.2013.05.114

[16] A.H. Saberi, O.M. Lai, M.S. Miskandar, "Melting and Solidification Properties of Palm-Based Diacylglycerol, Palm Kernel Olein, and Sunflower Oil in the Preparation of Palm-Based Diacylglycerol-Enriched Soft Tub Margarine," Food and Bioprocess Technology, 5(5), 1674-1685, 2012, doi:10.1007/s11947-010-0475-5.

[17] M. Naderi, J. Farmani, L. Rashidi, "Structuring of Chicken Fat by
Monoacylglycerols," JAOCS, Journal of the American Oil Chemists' Society, 93(9), 1221-1231, 2016, doi:10.1007/s11746-016-2870-1.

[18] Z. Zhang, X. Ma, H. Huang, G. Li, Y. Wang, "Enzymatic Production of Highly Unsaturated Monoacyglycerols and Diacylglycerols and Their Emulsifying Effects on the Storage Stability of a Palm Oil Based Shortening System," JAOCS, Journal of the American Oil Chemists' Society, 94(9), 1175-1188, 2017, doi:10.1007/s11746-017-3023-x.

[19] C.A. Ferretti, M.L. Spotti, J.I. Di Cosimo, "Diglyceride-rich oils from glycerolysis of edible vegetable oils," Catalysis Today, 302(November 2016), 233-241, 2018, doi:10.1016/j.cattod.2017.04.008.

[20] C.M. Yeoh, E.T. Phuah, T.K. Tang, W.L. Siew, L.C. Abdullah, T.S.Y. Choong, "Molecular distillation and characterization of diacylglycerolenriched palm olein," European Journal of Lipid Science and Technology, 116(12), 1654-1663, 2014, doi:10.1002/ejlt.201300502.

[21] A.C. Ferro, P.K. Okuro, A.P. Badan, R.L. Cunha, "Role of the oil on glyceryl monostearate based oleogels," Food Research International, 120(November 2018), 610-619, 2019, doi:10.1016/j.foodres.2018.11.013.

[22] O.G. Rocha-Amador, J.A. Gallegos-Infante, Q. Huang, N.E. Rocha-Guzman, M. Rociomoreno-Jimenez, R.F. Gonzalez-Laredo, "Influence of commercial saturated monoglyceride, mono-/diglycerides mixtures, vegetable oil, stirring speed, and temperature on the physical properties of organogels," International Journal of Food Science, 2014, 2014, doi:10.1155/2014/513641.

[23] E. Yilmaz, M. Öğütcü, "Properties and stability of hazelnut oil organogels with beeswax and monoglyceride," JAOCS, Journal of the American Oil Chemists' Society, 91(6), 1007-1017, 2014, doi:10.1007/s11746-014-24341 .

[24] J.D. Pérez-Martínez, M. Sánchez-Becerril, A.G. Marangoni, J.F. ToroVazquez, J.J. Ornelas-Paz, V. Ibarra-Junquera, "Structuration, elastic properties scaling, and mechanical reversibility of candelilla wax oleogels with and without emulsifiers," Food Research International, 122(January), 471-478, 2019, doi:10.1016/j.foodres.2019.05.020.

[25] U.T. Bornscheuer, "Lipase-catalyzed syntheses of monoacylglycerols," Enzyme and Microbial Technology, 17(7), 578-586, 1995, doi:10.1016/0141-0229(94)00096-A.

[26] N. Zhong, X. Deng, J. Huang, L. Xu, K. Hu, Y. Gao, "Low-temperature chemical glycerolysis to produce diacylglycerols by heterogeneous base catalyst," European Journal of Lipid Science and Technology, 116(4), 470 476, 2014, doi:https://doi.org/10.1002/ejlt.201300438.

[27] H. Noureddini, D.W. Harkey, M.R. Gutsman, "A Continuous Process for the Glycerolysis of Soybean Oil," JAOCS, Journal of the American Oil Chemists' Society, 81(2), 203-207, 2004.

[28] N. Zhong, L.-Z. Cheong, X. Xu, "Strategies to obtain high content of monoacylglycerols," European Journal of Lipid Science and Technology, 116(2), 97-107, 2014, doi:https://doi.org/10.1002/ejlt.201300336.

[29] V. Brei, G. Starukh, S. Levytska, D. Shistka, "Study of a Continuous Process of Glycerolysis of Rapeseed Oil with The Solid Base Catalysts," Chemistry and Chemical Technology, 6(1), 89-94, 2012, doi:10.23939/chcht06.01.089.

[30] S.K. Lo, C.P. Tan, K. Long, M.S.A. Yusoff, O.M. Lai, "Diacylglycerol oilproperties, processes and products: A review," Food and Bioprocess Technology, 1(3), 223-233, 2008, doi:10.1007/s11947-007-0049-3.

[31] E. Subroto, R.L. Nurannisa, "The Recent Application Of Palm Stearin In Food Industry : A Review," International Journal of Scientific \& Technology Research, 9(02), 2593-2597, 2020.

[32] R. O’Brien, Fats and Oils: Third Edition, 2009, doi:10.1016/j.ijbiomac.2015.07.020.

[33] A. Mulyawan, D. Hunaefi, P. Hariyadi, "Structured Lipid Characteristics of Enzimatic Transesterification Between Fish Oil and Virgin Coconut Oil," Jurnal Pengolahan Hasil Perikanan Indonesia, 21(2), 317-327, 2018.

[34] A.P. Arum, C. Hidayat, Supriyanto, "Synthesis of Emulsifier from Refined Bleached Deodorized Palm Stearin by Chemical Glycerolysis in Stirred Tank Reactor," KnE Life Sciences, 4(11), 130, 2019, doi:10.18502/kls.v4i11.3859.

[35] E. Subroto, M.F. Wisamputri, Supriyanto, T. Utami, C. Hidayat, "Enzymatic and chemical synthesis of high mono- and diacylglycerol from palm stearin and olein blend at different type of reactor stirrers," Journal of the Saudi Society of Agricultural Sciences, 19(1), 31-36, 2020, doi:10.1016/j.jssas.2018.05.003.

[36] F.D. Gunstone, Food applications of lipids. In: Food Lipids Chemisty, Nutrition, and Biotechnology, 2nd ed., Marcel Dekker, Inc, New York, 2002.

[37] R.C. Basso, A.P.B. Ribeiro, M.H. Masuchi, L.A. Gioielli, L.A.G. Gonçalves, A.O. dos Santos, L.P. Cardoso, R. Grimaldi, "Tripalmitin and monoacylglycerols as modifiers in the crystallisation of palm oil," Food Chemistry, 122(4), 1185-1192, 2010, doi:10.1016/j.foodchem.2010.03.113.

[38] M.M.C. Feltes, D. de Oliveira, J.M. Block, J.L. Ninow, "The Production, 
Benefits, and Applications of Monoacylglycerols and Diacylglycerols of Nutritional Interest," Food and Bioprocess Technology, 6(1), 17-35, 2013, doi:10.1007/s11947-012-0836-3.

[39] Z. Zhang, Y. Wang, X. Ma, E. Wang, M. Liu, R. Yan, "Characterisation and oxidation stability of monoacylglycerols from partially hydrogenated corn oil," Food Chemistry, 173, 70-79, 2014, doi:10.1016/j.foodchem.2014.09.155.

[40] R. Hoshina, Y. Endo, K. Fujimoto, "Effect of Triacylglycerol Structures on The Thermal Oxidative Stability of Edible Oil," JAOCS, Journal of the American Oil Chemists' Society, 81(5), 461-465, 2004, doi:10.1007/s11746-004-0923-6.

[41] A.F. Trasarti, D.J. Segobia, C.R. Apesteguía, F. Santoro, F. Zaccheria, N. Ravasio, "Selective Hydrogenation of Soybean Oil on Copper Catalysts as a Tool Towards Improved Bioproducts," JAOCS, Journal of the American Oil Chemists' Society, 89(12), 2245-2252, 2012, doi:10.1007/s11746-0122119-6.

[42] B. Cheirsilp, P. Jeamjounkhaw, A. H-Kittikun, "Optimizing an Alginate Immobilized Lipase for Monoacylglycerol Production by the Glycerolysis Reaction,” Journal of Molecular Catalysis B: Enzymatic, 59(1-3), 206-211, 2009, doi:10.1016/j.molcatb.2009.03.001.

[43] W. Kaewthong, S. Sirisansaneeyakul, P. Prasertsan, A. H-Kittikun, "Continuous production of monoacylglycerols by glycerolysis of palm olein with immobilized lipase," Process Biochemistry, 40(5), 1525-1530, 2005, doi:10.1016/j.procbio.2003.12.002.

[44] F.O. Nitbani, Juminaa, D. Siswanta, E.N. Solikhah, "Reaction path synthesis of monoacylglycerol from fat and oils," International Journal of Pharmaceutical Sciences Review and Research, 35(1), 126-136, 2015.

[45] G.P. McNeill, D. Borowitz, R.G. Berger, "Selective Distribution of Saturated Fatty Acids Into The Monoglyceride Fraction During Enzymatic Glycerolysis," Journal of the American Oil Chemists' Society, 69(11), 1098-1103, 1992, doi:10.1007/BF02541043.

[46] N. Zhong, L. Li, X. Xu, L. Cheong, B. Li, S. Hu, X. Zhao, "An Efficient Binary Solvent Mixture for Monoacylglycerol Synthesis by Enzymatic Glycerolysis," JAOCS, Journal of the American Oil Chemists' Society, 86(8), 783-789, 2009, doi:10.1007/s11746-009-1402-7.

[47] G.P. McNeill, S. Shimizu, T. Yamane, "Solid Phase Enzymatic Glycerolysis of Beef Tallow Resulting in a High Yield of Monoglyceride," Journal of the American Oil Chemists' Society, 67(11), 779-783, 1990, doi:10.1007/BF02540491

[48] W.D. Bossaert, D.E. De Vos, W.M. Van Rhijn, J. Bullen, P.J. Grobet, P.A. Jacobs, "Mesoporous Sulfonic Acids as Selective Heterogeneous Catalysts for the Synthesis of Monoglycerides," Journal of Catalysis, 182(1), 156-164, 1999, doi:10.1006/jcat.1998.2353.

[49] D. Isabel, F. Mohino, E. Sastre, "Synthesis of MCM-41 Materials Functionalised with Dialkylsilane Groups and Their Catalytic Activity," Applied Catalysis A: General, 242, 161-169, 2003.

[50] S. Gan, H.K. Ng, P.H. Chan, F.L. Leong, "Heterogeneous Free Fatty Acids Esterification in Waste Cooking Oil Using Ion-exchange Resins," Fuel $\begin{array}{llll}\text { Processing Technology, } & \text { 102, 67-72, }\end{array}$ doi:10.1016/j.fuproc.2012.04.038

[51] G. Widiyarti, M. Hanafi, W.P. Soewarso, "Study On The Synthesis Of Monolaurin As Antibacterial Agent Againts Staphylococcus aureus," Indonesian Journal of Chemistry, 9(1), 99-106, 2010, doi:10.22146/ijc.21569.

[52] T. Kimmel, Kinetic Investigation of the Base-Catalyzed Glycerolysis of Fatty Acid Methyl Esters, Berlin, 2004.

[53] G.L. Hasenhuettl, Food Emulsiers and Their Applications : Third Edition, Springer Nature Switzerland, 2019.

[54] A. Prianti, "The Effect of Temperature and Concentration of $\mathrm{NaOH}$ in Production of Monoglycerol and Diglycerol from Crude Palm Oil," Jurnal Riset Teknologi Industri, 6(11), 13-20, 2012.

[55] N.F. Nasir, W.R.W. Daud, S.K. Kamarudin, Z. Yaakob, "Methyl Esters Selectivity of Transesterification Reaction with Homogenous Alkaline Catalyst to Produce Biodiesel in Batch, Plug Flow, and Continuous Stirred Tank Reactors," International Journal of Chemical Engineering, 2014, 931264, 2014, doi:10.1155/2014/931264.

[56] Q. Shu, J. Gao, Z. Nawaz, Y. Liao, D. Wang, J. Wang, "Synthesis of Biodiesel from Waste Vegetable Oil with Large Amounts of Free Fatty Acids using A Carbon-based Solid Acid Catalyst," Applied Energy, 87(8), 2589-2596, 2010, doi:10.1016/j.apenergy.2010.03.024.

[57] A. Sivasamy, K.Y. Cheah, P. Fornasiero, F. Kemausuor, S. Zinoviev, S. Miertus, "Catalytic Applications in the Production of Biodiesel from Vegetable Oils," ChemSusChem, 2(4), 278-300, 2009, doi:https://doi.org/10.1002/cssc.200800253.

[58] Z. Helwani, M.R. Othman, N. Aziz, J. Kim, W.J.N. Fernando, "Solid

www.astesj.com
Heterogeneous Catalysts for Transesterification of Triglycerides with Methanol: A Review,” Applied Catalysis A: General, 363(1-2), 1-10, 2009, doi:10.1016/j.apcata.2009.05.021.

[59] Istadi, Katalis Reaksi Kimia, Graha Ilmu, Yogyakarta, 2011

[60] A.K. Endalew, Y. Kiros, R. Zanzi, "Inorganic Heterogeneous Catalysts for Biodiesel Production from Vegetable Oils," Biomass and Bioenergy, 35(9), 3787-3809, 2011, doi:10.1016/j.biombioe.2011.06.011.

[61] Y. Huang, Y. Gao, N. Zhong, "Selective production of diacylglycerols through glycerolysis by ionic liquid: 1-butyl-3-methylimidazolium imidazolide as catalyst and reaction medium," Journal of the American Oil Chemists' Society, 92(6), 927-931, 2015, doi:10.1007/s11746-015-2650-3.

[62] H.R. Ong, M.M.R. Khan, R. Ramli, R.M. Yunus, M.W. Rahman, "Glycerolysis of Palm Oil Using Copper Oxide Nanoparticles Combined with Homogeneous Base Catalyst," New Journal of Chemistry, 40(10), 8704-8709, 2016, doi:10.1039/c6nj01461e.

[63] C.S. Galúcio, R.A. Souza, M.A. Stahl, P. Sbaite, C.I. Benites, M.R.W. Maciel, "Physicochemical Characterization of Monoacylglycerols from Sunflower Oil," Procedia Food Science, 1(Icef 11), 1459-1464, 2011, doi:10.1016/j.profoo.2011.09.216.

[64] D.T. Hartanto, Rochmadi, Budhijanto, "Mechanism and kinetic model for glycerolysis of shellac," IOP Conference Series: Materials Science and Engineering, 778, 12053, 2020, doi:10.1088/1757-899x/778/1/012053.

[65] H.R. Ong, M.M.R. Khan, R. Ramli, R.M. Yunus, M.W. Rahman, "Glycerolysis of palm oil using copper oxide nanoparticles combined with homogeneous base catalyst," New Journal of Chemistry, 40(10), 8704-8709, 2016, doi:10.1039/c6nj01461e.

[66] V.B. Veljković, I.B. Banković-Ilić, O.S. Stamenković, "Purification of Crude Biodiesel Obtained by Heterogeneously-Catalyzed Transesterification," Renewable and Sustainable Energy Reviews, 49, 500 516, 2015, doi:10.1016/j.rser.2015.04.097.

[67] A. Corma, S. Iborra, S. Miquel, J. Primo, "Catalysts for The Production of Fine Chemicals: Production of Food Emulsifiers, Monoglycerides, by Glycerolysis of Fats with Solid Base Catalysts," Journal of Catalysis, 173(2), 315-321, 1998, doi:10.1006/jcat.1997.1930.

[68] J. Barrault, F. Jerome, "Design of New Solid Catalysts for The Selective Conversion of Glycerol," European Journal of Lipid Science and Technology, 110(9), 825-830, 2008, doi:10.1002/ejlt.200800061.

[69] A. Prihanto, T.A.B. Irawan, "Effect of Temperature, Catalyst Concentration and Methanol-Oil Molar Ratio Against Biodiesel Yield from Used Cooking Oil Through Neutralization Transesterification Process," Metana, 13(1), 3036, 2017, doi:10.14710/metana.v13i1.11340.

[70] S.M. Hingu, P.R. Gogate, V.K. Rathod, "Synthesis of Biodiesel from Waste Cooking Oil using Sonochemical Reactors," Ultrasonics Sonochemistry, 17(5), 827-832, 2010, doi:10.1016/j.ultsonch.2010.02.010. 